청예사료작물과 볏짚 위주의 완전배합발효사료 급여가 Holstein 착유우의 생산성에 미치는 영향

이현준*김현섭*·기광석*.정하연*백광수*김준식*조광근**.조재순***이홍구***.

우정희****:최윤재****

축산기술연구소*, 진주산업대학교**, 서울대학교 농생명공학부***,

미국 메릴랜드주 국립보건원 분자생물학연구실****

\title{
Effects of Total Mixed Fermentation Feeds Based on Rice-straw and Six Forage Crops on the Productivity of Holstein Cows
}

\author{
H. J. Lee*, H. S. Kim*, K. S. Ki*, H. Y. Jeong*, K. S. Baek*, J. S. Kim*, K. K. Cho**, \\ J. S. Cho***, H. G. Lee***, J. H. Woo**** and Y. J. Choi*** \\ National Livestock Research Institute*, Jinju National University**, School of Agricultural \\ Biotechnology, Seoul National University***, Section on Biophysical Chemistry, Laboratory of \\ Molecular Biology, National Institute of Mental Health, Bethesda, Maryland 20892, USA****
}

\begin{abstract}
This experiment was carried out to evaluate the value of total mixed fermentation feeds(TMFF) as completely mixed ration and to observe the effect of various kinds of TMFF on the palatability, feed intake, and milk performance in Holstein cows. The dry matter (DM) content of TMFF used in the experiment was $23.98 \sim 28.42 \%$ range, and CP, TDN, ADF and NDF were $16.2 \sim 19.2 \%, 58.3 \sim 65.1 \%$, $34.4 \sim 39.6 \%$ and $46.9 \sim 49.9 \%$ levels, respectively. The relative feed value (RFV) in rape-, alfalfa-, grass-, oat-, corn-TMFF groups were 138.6, 133.9, 116.5, 111.8, 111.4 and 108.1, respectively. Among these groups, RFV of rye-TMFF group was lowest. Dry matter disappearance(DMD) showed $0.8 \sim 1.9 \%$ to the all kinds of TMFF groups. The $\mathrm{pH}$ was $3.89 \sim 4.87$ and $\mathrm{NH}_{3}-\mathrm{N}$ concentration was $6.93 \sim 8.66$ $\mathrm{mg} / \mathrm{dl}$. The acetic acid concentration in the raw material of TMFF showed low level of $0.19 \sim 0.57 \%$, lactic acid showed high level of $1.17 \sim 3.21 \%$ and butyric acid was very high as $0.03 \sim 0.32 \%$. Therefore, these results provide evidence that the quality of TMFF was not so bad. In the daily fresh matter intake on the alfalfa-, grass-, rape-, corn-, oats- and rye-TMFF were showed 62.85, 60.48, 58.04, $57.11,54.61$ and $45.74 \mathrm{~kg}$ respectively. All TMFF showed high palatability as daily dry matter intake of 1.95 to $2.90 \%$ by body weight of experimental cows. Body condition score(BCS) was gradually increased in during 60 days of the experiment term. Average daily gain(ADG) showed about
\end{abstract}

본 논문은 농림부에서 시행한 1994년도 농림기술개발사업 (현장애로과제)에 의한 연구 결과입니다.

Corresponding author: H. J. Lee, National Livestock Research Institute, R. D. A, 330-801, Korea E-mail : dadim922@rda.go.kr Tel : 041-580-3450 Fax : 041-580-3385 
26.7g. In alfalfa-TMFF group, the ADG was higher than in the other groups $(\mathrm{p}<0.05)$. Also, the n BCS was observed in grass-TMFF group (3.07 to 3.34) and rye-TMFF group was decreased in $.34(\mathrm{p}<0.05)$. The milk yield appropriately showed a range of $16.16 \sim 18.95 \mathrm{~kg}$ in all groups. hese groups, alfalfa-TMFF group was highest $(\mathrm{P}<0.05)$. Average milk fat contents showed high $4.06 \sim 4.79 \%$ and the level was high in order of rape-, grass-, corn-, alfalfa-, rye- and F. Milk protein was highest in forage-TMFF and level of lactose in milk was approximately overall groups. Solid non fat(SNF) and total solid(TS) contents were $8.75 \%$ and $12.8 \%$, ly. However, milk composition was not significantly affected by TMFF.

ds : TMFF, BCS, ADG, Daily milk yield, Milk composition, Palatability)

\section{I. 서 론}

볏짚은 조사료생산기반이 절대적으로 부족한 우리나라의 대표적인 고간류이지만 기호성과 소화율이 낮다는 문제점이 있어 이에 많은 연 구자들이 암모니아처리 등의 화학적 처리기술 을 보급하여 볏짚의 이용성 증진에 많은 기여 를 했지만(신과 박, 1980 ; 김 등, 1989 ; 문 등, 1990; 하 등, 1993; 문, 1994) 최근 들어 수입조 사료에 밀려 외면되고 있다. 한편, 볏짚의 이용 성 증진을 위한 또 다른 방법으로서 볏짚의 사 일리지화에 대한 연구가 이루어졌으며, 이러한 방법에는 가성소다처리 볏짚의 사일리지화, 생 볏짚과 옥수수의 사일리지화, 볏짚과 청예호맥 의 사일리지화, 볏짚과 서류 및 채소류의 사일 리지화, 볏짚과 당밀 및 유산균첨가 사일리지 화가 포함되며, 이들 방법으로 건물 및 유기영 양소의 소화율이 $20 \sim 30 \%$ 정도 증진된다고 보 고하였다 (고와 송, 1977; 이 등, 1977; 강 등, 1980). 그러나 이러한 볏짚 사일리지화 방법은 또 하나의 사일리지 제조기법으로서의 가치가 인정되고 볏짚 이용성 확대에 대한 가능성을 열어 주었지만 사료로서의 영양 수준은 매우 낮아 젖소의 생명활동에 필요한 영양소 공급을 단일화하고자 하는 완전사료 공급체계와는 다 소 거리가 있는 것이다.

또한, 1986년 McCullough은 자유채식 조건에 서 단일사료원으로서 사일리지를 이용하는 최 적 사일리지 사료 프로그램을 개발하였는데, 이를 TMR 사일리지, 완전배합 사일리지 또는 All-in One 사일리지라고 하였다. 완전배합사료 의 사일리지 제조원리는 사료작물 청초와 사과 박 등 농산가공부산물들이 함유한 다량의 수분
이 사일리지 제조과정 중 진압과 침출에 의해 저수분재료인 볏짚과 단미사료들로 전이되어 재 료간 수분의 평형을 이루게되고 사일리지 발효 과정에서 수분흡수와 발효균의 활동에 의해 반 추위 미생물이 직접 이용하기 어려운 고간류 등 농산부산물들의 세포벽물질이 연화 또는 파괴됨 으로써 반추 미생물의 이용을 증진시키게 되는 것이다. 이전의 볏짚에 대한 화학적 처리와는 다른 물리적-생물학적 처리 기술인 것이다.

한편, 어떠한 단일사료나 혼합사료가 가축에 게 급여되기 전에 먼저 정확한 영양성분의 분 석을 통한 영양평가와 급여 대상 가축에 대한 기호성 평가가 매우 중요하다. 특히, 대량급여 사료인 사일리지, total mixed ration(TMR) 등의 사료가치평가에서 함유된 영양성분이상으로 중 요한 것이 기호성이 될 것이다. 기호성은 급여 대상 가축별, 성장단계별, 생리적 단계별 일일 최대 섭취량으로 나타내어져야 할 것이다. 어 떤 사료자원에 대한 가축의 일일 최대섭취량을 안다는 것은 그 사료자원의 생산 또는 확보된 양과 계획적인 급여기간을 설정하게 한다. 그 리고 최대 섭취량을 초과하지 않는 양의 급여 와 고 생산기에 있는 젖소의 부족한 영양소 요 구량을 보충하기 위한 농후사료의 추가공급량 을 결정하게 하는 요소이며 또한 가축의 과학 적인 영양관리를 위한 가장 중요한 요소임에도 아직도 이러한 완전사료 혹은 단일사료에 대한 젖소의 최대섭취량을 조사하여 공급량을 결정 하고 사양의 지침을 제공하는 연구는 이루어진 바가 없다.

그래서 본 연구는 볏짚과 고수분 사료자원인 청초를 주 원료로 하여 젖소용 완전사료 또는 단일기초사료를 목적으로 적절한 곡류와 배합 
한 뒤 사일로에 저장하여 제조한 완전배합발효 사료(total mixed fermentation feeds; TMFF)에 대하여 젖소 착유우에 대한 완전사료로서의 가 치를 비교 평가하고 일일공급량을 결정하기 위 한 기초자료를 얻고자 일련의 젖소 사양실험을 수행하였다.

\section{․ 재료 및 방법}

\section{1. 시험사료의 제조}

$\mathrm{TMFF}$ 의 제조는 6종(혼합목초, 알팔파, 옥수 수, 호맥, 연맥, 유채)의 고수분원료로서의 사료 작물을 초종별로 청초를 수확하고, 옥수수, 콩, 밀기울 및 볏짚을 표 1에서 보는 바와 같이 배 합하였다. 원료사료의 전처리는 볏짚은 $3 \sim 5 \mathrm{~cm}$ 단위로 볏짚 절단기로 절단한 후 이물질 제거 와 TMFF의 배합촉진과 수분조절을 위하여 15 분간 수침 세척한 후 제조에 사용하였으며, 원
료 곡류인 대두(콩)와 옥수수는 무가공된 알곡 을 구입하지 못하여 대두박, 파쇄 옥수수로 각 각 대체하였으며, 젖소 사양시험용 $\mathrm{TMFF}$ 제조 시 콩은 대두박과 지방사료(Alifat)를 $75.73 \%$ 및 $24.27 \%$ 씩 각각 대치하여 제조하였다.

모두 6종의 사료작물들을 수확하여 40ton 규 모 $\left(44 \mathrm{~m}^{2}\right)$ 의 지하식방카 사일로에 각각 배합하 고 인력과 스키드로다를 이용하여 충분히 진압 하여 최대한량을 용기에 충진하였다. 그 후 비 닐과 보온덮게를 각각 이중으로 덮고 상층부에 $30 \mathrm{~kg}$ 들이 석분포대 등을 15 개씩 올려 진압하 였다.

그리고 모든 $\mathrm{TMFF}$ 들은 제조 후 60 일 이상 경과한 후 사양시험 개시 하루 전에 동시에 개 봉하여 품질평가 및 사양시험에 공시하였다.

\section{2. 시험동물}

표 2와 같이 홀스타인 착유우 42 두를 사료작

Table 1. Ingredient compositions of TMFFs(\%)

\begin{tabular}{|c|c|c|c|c|c|c|}
\hline $\begin{array}{ll} & \text { Feedstuffs } \\
\text { TMFFs } & \end{array}$ & Soybean & Corn & $\begin{array}{l}\text { Wheat } \\
\text { bran }\end{array}$ & $\begin{array}{l}\text { Rice } \\
\text { straw }\end{array}$ & $\begin{array}{l}\text { Fresh } \\
\text { forage }\end{array}$ & Total \\
\hline Corn & 2.63 & 4.42 & 3.50 & 26.55 & 62.90 & 100 \\
\hline Grass & 2.00 & 5.00 & 8.31 & 23.31 & 61.38 & 100 \\
\hline Rye & 1.67 & 4.17 & 3.33 & 45.83 & 45.00 & 100 \\
\hline Rape & 1.49 & 4.51 & 3.01 & 45.68 & 45.31 & 100 \\
\hline Alfalfa & 0.21 & 9.23 & 0.22 & 27.85 & 62.49 & 100 \\
\hline Oat & 1.69 & 4.56 & 3.45 & 43.07 & 47.23 & 100 \\
\hline
\end{tabular}

Table 2. Animals and treatments for experiment

\begin{tabular}{|c|c|c|c|c|c|c|c|c|}
\hline \multirow{2}{*}{ Items } & \multicolumn{6}{|c|}{ TMFFs } & \multirow{2}{*}{ Mean } & \multirow{2}{*}{ SEM } \\
\hline & Corn & Grass & Rye & Rape & Alfalfa & Oat & & \\
\hline Heads & 7 & 7 & 7 & 7 & 7 & 7 & 7 & \\
\hline Months & 44.7 & 43.9 & 44 & 45.8 & 41.9 & 45.2 & 44.3 & 0.24 \\
\hline Parity & 2.4 & 2.39 & 2.34 & 2.42 & 2.38 & 2.41 & 2.4 & 0.03 \\
\hline Days of Lactation & 239.8 & 238.7 & 240 & 241.1 & 238.9 & 240.3 & 239.8 & 3.27 \\
\hline Daily milk yield(Kg) & 19.8 & 20.6 & 22.2 & 20.3 & 21.9 & 22.6 & 21.2 & 0.42 \\
\hline Body weight(Kg) & 577.7 & 578.5 & 569.8 & 575.2 & 567.1 & 579 & 574.6 & 6.48 \\
\hline BCS & 3.13 & 3.07 & 3.34 & 3.11 & 3.23 & 3.37 & 3.2 & 0.01 \\
\hline
\end{tabular}


물 TMFF 6종류별로 각 7두씩 건강과 산차 및 산유능력이 비슷하게 완전임의배치하여 개체별 급여시험을 수행하였다. TMFF 종류별로 기호 성(일일최대섭취량)과 산유량, 체중 등의 변화 를 조사하였다. 공시축의 시험 개시 직전 평균 월령은 44.3월, 산차는 2.4산, 유기는 239.8일, 일일 두당 산유량은 $21.2 \mathrm{~kg}$, 체중은 $574.6 \mathrm{~kg}$, 체충실지수(Body condition score; BCS)는 3.2이 었다.

\section{3. 조사항목 및 조사방법}

(1) 젓소 급여시험 및 사료섭취량 조사

공시축은 제조 후 60 일 이상을 경과한 $\mathrm{TMFF}$ 를 종류별로 각 7 두씩 나누어 개체사양 을 수행하였으며, 1일 2회 $(9: 00,18: 00)$ 충분히 남을 정도로 급여하였다. 물은 항상 자유롭게 섭취할 수 있게 하였으며, 비타민과 광물질은 축산기술연구소 관행에 따른 혼합제를 1 일 두 당 $150 \mathrm{~g}$ 씩 급여하였다. TMFF의 잔량은 매일 9시에 각각 측정하여 일일 섭취량을 조사하였 다. 기타 사양관리는 축산기술연구소 관행에 준하였다.

(2) TMFF의 사료적 가치 분석

1) 일반성분의 분석

시험사료의 일반분석은 $\mathrm{AOAC}$ 법(1990)에 의 한 화학적 분석을 수행하였다.

2) 상대적사료가치(RFV: Relative Feed Value)

$\mathrm{RFV}$ 는 아래와 같은 $\mathrm{ADF}$ 및 $\mathrm{NDF}$ 값을 이용 한 Holland 등(1990)의 공식으로 계산하였다.

$\mathrm{RFV}=\{88.9-(0.78 \times \mathrm{ADF} \%)\} \times(120 \div \mathrm{NDF} \%) \div 1.29$

3) $\mathrm{TMFF}$ 의 $\mathrm{pH}$, 암모니아태 질소 $\left(\mathrm{NH}_{3}-\mathrm{N}\right)$ 및 유기산 측정

TMFF의 $\mathrm{pH}$ 는 digital $\mathrm{pH}$ meter(HANNA, $\mathrm{USA}$ )로 측정하였고, $\mathrm{NH}_{3}-\mathrm{N}$ 는 Chaney와 Marb$\mathrm{ach}(1962)$ 의 방법에 준하여 Spectrophotometer (UV-1201, SHIMADZU, JAPAN)의 파장 $630 \mathrm{~nm}$ 에서 $\mathrm{OD}$ (흡광도)를 측정하여 계산하였다. 초산, 프로피온산, 부틸산 등의 휘발성지방산의 분석
은 Erwin 등(1961)의 방법에 의하여 시료희석 액 $5 \mathrm{ml}$ 에 $\mathrm{HgCl}_{2} 1 \mathrm{ml}$ 와 metaphosphate $0.25 \mathrm{ml}$ 를 첨가한 후 $3,500 \mathrm{rpm}$ 에 20 분간 원심분리하 여 $-20^{\circ} \mathrm{C}$ 에 보관하였다가 Gas chromatography (Varien 6,000 Vista, USA)로 농도를 측정하였다.

(3) 산유량, 체중 및 $\mathrm{BCS}$ 조사

매 10 일 간격으로 공시축 개체별 유량과 유 성분량을 조사하였고, 매월 1 회의 체중조사를 우형기를 이용하여 측정(매월 20 일, 오전 10 시) 하였으며, 체중 측정시에 개체별 체충실지수 (BCS)는 Edmonson 등(1989)의 8개 부위별 평 가에 의한 방법으로 조사하였다.

\section{(4) 통계 분석}

측정된 자료는 SAS 통계 Package (1995)를 이용하여 분산분석을 실시하였고, 처리간 유의 성 검정은 Duncan's multiple range test (Duncan, 1955)를 이용하였다.

\section{III. 결과 및 고찰}

\section{1. 시험사료의 영양성분 함량 및 품질}

젖소사양시험에 공시하기 전에 제조 보관 중 이던 $\mathrm{TMFF}$ 를 개봉하여 분석하였는데, 먼저 사 료작물 청예를 주종으로 하는 $\mathrm{TMFF}$ 의 영양성 분 함량은 표 3 에서 보는 바와 같다. $\mathrm{TMFF}$ 의 평균 건물 함량은 옥수수-, 연맥-, 알팔파-, 혼 합목초-, 호맥-, 유채-TMFF에서 각각 28.42 , $27.08,26.77,26.45,24.76,23.98 \%$ 의 순서로 높 게 나타났는데 $(\mathrm{P}<0.05)$, 이는 배합중의 수분 함 량의 오차나 발효과정중 초종별 특성 등 여러 가지 요인이 작용한 결과로 사료된다.

그리고 조단백질 함량은 알팔파-, 혼합목초-, 연맥-, 호맥-, 옥수수-, 유채-TMFF가 각각 $19.2,17.2,17.2,16.8,16.4,16.2 \%$ 의 순서로 높 게 나타내었으며, 가소화에너지 총량(TDN)에 있어서는 알팔파-, 유채-, 혼합목초-, 연맥-, 옥수수- 및 호맥-TMFF에서 65.1, 65.0, 60.2, $59.3,58.4$ 및 $58.3 \%$ 의 순서로 나타났다. 그리 고 $\mathrm{ADF}$ 함량은 $34.4 \sim 39.6 \%$ 범위에서, $\mathrm{NDF}$ 
Table 3. Chemical composition of TMFFs (DM \%)

\begin{tabular}{ccccccccc}
\hline TMFFs & $\begin{array}{c}\text { Dry } \\
\text { matter }\end{array}$ & $\begin{array}{c}\text { Crude } \\
\text { protein }\end{array}$ & TDN & P & Ca & ADF & NDF & RFV \\
\hline \hline Corn & $28.42^{\mathrm{a}}$ & $16.4^{\mathrm{c}}$ & 58.4 & 0.26 & 0.68 & $38.3^{\mathrm{a}}$ & $49.3^{\mathrm{a}}$ & $111.4^{\mathrm{ab}}$ \\
Grass & $26.45^{\mathrm{ab}}$ & $17.2^{\mathrm{bc}}$ & 60.2 & 0.31 & 0.87 & $38.2^{\mathrm{a}}$ & $47.2^{\mathrm{a}}$ & $116.5^{\mathrm{ab}}$ \\
Rye & $24.76^{\mathrm{b}}$ & $16.8^{\mathrm{bc}}$ & 58.3 & 0.30 & 0.74 & $39.6^{\mathrm{a}}$ & $49.9^{\mathrm{a}}$ & $108.1^{\mathrm{b}}$ \\
Rape & $23.98^{\mathrm{b}}$ & $16.2^{\mathrm{c}}$ & 65.0 & 0.34 & 0.96 & $34.3^{\mathrm{b}}$ & $41.7^{\mathrm{b}}$ & $138.6^{\mathrm{a}}$ \\
Alfalfa & $26.77^{\mathrm{a}}$ & $19.2^{\mathrm{a}}$ & 65.1 & 0.42 & 1.29 & $37.2^{\mathrm{a}}$ & $46.9^{\mathrm{ab}}$ & $133.9^{\mathrm{a}}$ \\
Oat & $27.08^{\mathrm{a}}$ & $17.2^{\mathrm{bc}}$ & 59.3 & 0.33 & 0.84 & $39.4^{\mathrm{a}}$ & $48.4^{\mathrm{a}}$ & $111.8^{\mathrm{ab}}$ \\
Mean & 26.24 & 17.17 & 61.05 & 0.33 & 0.90 & 37.83 & 46.35 & 120.06 \\
SEM & 1.35 & 0.74 & 4.61 & 0.06 & 0.15 & 2.16 & 3.34 & 8.58 \\
\hline
\end{tabular}

ADF : acid detergent fiber; NDF : neutral detergent fiber.

TDN : total digestible nutrients; RFV : relative feed value.

SEM : standard error of mean.

a,b,c Means with the different letter within same row are significantly $\operatorname{different}(\mathrm{P}<0.05)$.

함량은 $46.9 \sim 49.9 \%$ 범위를 나타내어 상대적사 료가치(RFV)는 유채-, 알팔파-, 혼합목초-, 연 맥-, 옥수수- 및 호맥-TMFF에서 각각 138.6, $133.9,116.5,111.8,111.4,108.1$ 으로 나타났으 며 특히, 호맥-TMFF가 통계적으로 낮게 나타 났다 $(\mathrm{P}<0.05)$. 시험사료의 전체적인 성분 함량 의 편차는 본 시험에 공시된 사료의 배합목표 가 비슷한 수분 함량 $(75 \%)$ 로서 수분조절을 위 해 원료간 배합비가 다름으로 인한 것이었는 데, 목표수분을 $10 \%$ 정도 더 낮은 $65 \%$ 로 조정 하면 이러한 성분간 차이는 감소할 것으로 예 상되므로 앞으로 수분목표를 더 낮게 조정한 시험이 필요할 것으로 사료된다.

2. TMFF 종류별 제조 중 건물 손실률, $\mathrm{pH}$, 암모니아태 질소 및 유기산 함량

제조과정 중의 $\mathrm{TMFF}$ 의 품질변화를 조사하 기 위해 표면 부패량으로서 나타낸 건물손실율 에 있어서는 표 4에서와 같이 초종별 TMFF간 에는 혼합목초-, 옥수수-, 연맥-, 호맥-, 알팔 파-, 유채-TMFF의 순으로 나타내었고, 전체적 으로는 $0.8 \sim 1.9 \%$ 범위로서 낮게 나타내어 발 효와 보관상태가 좋은 것으로 나타내었다. 초 종별 $\mathrm{TMFF}$ 의 $\mathrm{pH}$ 는 $3.89 \sim 4.87$ 의 범위로 옥수 수-TMF 사료가 가장 낮고, 유채-, 알팔파-, 연
맥-, 목초-, 호맥-TMFF 순으로 높게 나타났으 며, 암모니아태 질소 $\left(\mathrm{NH}_{3}-\mathrm{N}\right)$ 함량은 전체적으 로 6.84 8.42의 범위에서 옥수수-TMF사료가 가장 낮고, 목초-, 연맥-, 호맥-, 유채-, 알팔파순으로 높게 나타났다 $(\mathrm{P}<0.05)$. 휘발성지방산 조성에 있어서 $\mathrm{TMFF}$ 원물 중 초산 함량은 $0.19 \sim 0.57 \%$ 범위에서 연맥-, 유채-, 옥수수-, 혼합목초-, 알팔파-, 호맥-TMFF의 순서로 유의 한 차이를 보였으나 대체적으로 낮은 수치를 나 타내었으며, 젖산 함량은 원물 $\mathrm{TMFF}$ 의 1.17 $3.21 \%$ 범위에서 옥수수-, 유채-, 알팔파-, 연맥-, 혼합목초-, 호맥-TMFF의 순서로 높게 나타내었 다. 그리고 불량발효산물로서 평가되는 부틸산 함량은 전체적으로 $0.03 \sim 0.32 \%$ 로 낮게 나타내 어 TMFF의 발효상태가 우수한 것을 알 수 있었 으며, 초종별 TMFF간의 부틸산 함량을 비교하 여 보면, 호맥-TMFF의 부틸산 함량이 $0.32 \%$ 로 유의하게 높은 것으로 나타내었다( $\mathrm{P}<0.05)$. TMFF 종류별 품질은 초종간 차이가 다소 있는 것으로 나타내었는데, 특히 호맥-TMFF의 암모니아태질 소 함량이 높고 부틸산 함량도 높은 것으로 나 타내어 발효성상이 가장 나빠 젖소의 기호성이 가장 나쁠 것으로 사료되었다.

3. TMFF 종류별 젖소의 기호성 및 체중 및 신체충실지수(BCS) 변화 
Table 4. Dry matter loss, $\mathrm{pH}, \mathrm{NH}_{3}-\mathrm{N}$ and organic acids of TMFFs

\begin{tabular}{|c|c|c|c|c|c|c|}
\hline \multirow{2}{*}{ TMFFs } & \multirow{2}{*}{$\begin{array}{c}\text { DM loss } \\
(\%)\end{array}$} & \multirow{2}{*}{$\mathrm{pH}$} & \multirow{2}{*}{$\begin{array}{l}\mathrm{NH}_{3}-\mathrm{N} \\
(\mathrm{mg} / \mathrm{dl})\end{array}$} & \multicolumn{3}{|c|}{ Volatile fatty acid(\%/FM) } \\
\hline & & & & Acetic acid & Lactic acid & Butyric acid \\
\hline Corn & $1.9^{\mathrm{a}}$ & $3.89^{\mathrm{b}}$ & $6.84^{\mathrm{c}}$ & $0.34^{\mathrm{b}}$ & $3.21^{\mathrm{a}}$ & $0.03^{\mathrm{c}}$ \\
\hline Grass & $2.1^{\mathrm{a}}$ & $4.65^{\mathrm{a}}$ & $7.04^{\mathrm{bc}}$ & $0.30^{\mathrm{b}}$ & $1.65^{\mathrm{bc}}$ & $0.04^{\mathrm{c}}$ \\
\hline Rye & $1.5^{\mathrm{a}}$ & $4.87^{\mathrm{a}}$ & $8.15^{\mathrm{a}}$ & $0.19^{c}$ & $1.17^{\mathrm{c}}$ & $0.32^{\mathrm{a}}$ \\
\hline Rape & $0.8^{\mathrm{b}}$ & $3.97^{\mathrm{b}}$ & $8.20^{\mathrm{a}}$ & $0.43^{\mathrm{a}}$ & $2.74^{\mathrm{a}}$ & $0.03^{\mathrm{c}}$ \\
\hline Alfalfa & $1.0^{\mathrm{ab}}$ & $4.24^{\mathrm{ab}}$ & $8.42^{\mathrm{a}}$ & $0.21^{\mathrm{c}}$ & $2.09^{b}$ & $0.13^{\mathrm{b}}$ \\
\hline Oat & $1.6^{\mathrm{a}}$ & $4.46^{\mathrm{a}}$ & $7.33^{\mathrm{b}}$ & $0.57^{\mathrm{a}}$ & $1.96^{\mathrm{b}}$ & 0.07 \\
\hline Mean & 1.48 & 4.35 & 7.66 & 0.34 & 2.14 & 0.10 \\
\hline SEM & 0.50 & 0.29 & 0.47 & 0.11 & 0.51 & 0.07 \\
\hline
\end{tabular}

DM loss ; Dry matter loss.

FM ; Fresh matter.

SEM ; Standard error of mean.

${ }_{\text {a,b,c }}$ Means with the different letter within same row are significantly $\operatorname{different}(\mathrm{P}<0.05)$.

Table 5. Effects of various TMFFs on DMI(\%), DBWG and BCS during the experimental periods in lactating cows

\begin{tabular}{|c|c|c|c|c|c|c|c|c|c|}
\hline \multirow{2}{*}{ Items } & & \multicolumn{6}{|c|}{ TMFFs } & \multirow{2}{*}{ Mean } & \multirow{2}{*}{ SEM } \\
\hline & & Corn & Grass & Rye & Rape & Alfalfa & Oat & & \\
\hline \multirow{2}{*}{ Intake } & $\mathrm{FMI}(\mathrm{Kg})$ & $57.11^{\mathrm{a}}$ & $60.48^{\mathrm{a}}$ & $45.74^{\mathrm{c}}$ & $58.04^{\mathrm{a}}$ & $62.85^{\mathrm{a}}$ & $54.61^{\mathrm{ab}}$ & 56.47 & 3.53 \\
\hline & DMI(\%/BW) & $2.80^{\mathrm{a}}$ & $2.76^{\mathrm{a}}$ & $1.95^{\mathrm{c}}$ & $2.40^{\mathrm{b}}$ & $2.90^{\mathrm{a}}$ & $2.55^{\mathrm{b}}$ & 2.56 & 0.17 \\
\hline \multirow{3}{*}{$\begin{array}{c}\text { Body } \\
\text { weight } \\
(\mathrm{Kg})\end{array}$} & Initial & 577.7 & 578.5 & 569.8 & 575.2 & 567.1 & 579.0 & 574.6 & 2.44 \\
\hline & Final & 596.3 & 597.2 & 578.2 & 586.9 & 586.7 & 596.8 & 590.4 & 5.49 \\
\hline & Difference & $18.6^{\mathrm{a}}$ & $18.7^{\mathrm{a}}$ & $8.4^{\mathrm{c}}$ & $11.7^{\mathrm{bc}}$ & $19.6^{\mathrm{a}}$ & $17.8^{\mathrm{a}}$ & 15.8 & 3.11 \\
\hline \multicolumn{2}{|c|}{ DBWG(g/d/hd) } & $310.0^{\mathrm{a}}$ & $311.7^{\mathrm{a}}$ & $140.0^{\mathrm{c}}$ & $195.0^{\mathrm{b}}$ & $326.7^{\mathrm{a}}$ & $297.4^{\mathrm{a}}$ & 263.5 & 43.19 \\
\hline \multirow{3}{*}{$\mathrm{BCS}$} & Initial & 3.13 & 3.07 & 3.34 & 3.11 & 3.23 & 3.37 & 3.21 & 0.09 \\
\hline & Final & 3.38 & 3.34 & 3.30 & 3.30 & 3.40 & 3.46 & 3.36 & 0.05 \\
\hline & Difference & $0.25^{\mathrm{a}}$ & $0.27^{\mathrm{a}}$ & $0.04^{\mathrm{c}}$ & $0.19^{\mathrm{b}}$ & $0.17^{\mathrm{b}}$ & $0.09^{c}$ & 0.17 & 0.05 \\
\hline
\end{tabular}

$\mathrm{FMI}(\mathrm{Kg})$; Fresh matter intake.

DMI(BW\%) ; Percentage of dry matter intake per body weight.

DBWG ; Daily body weight gain.

BCS ; Body condition score.

${ }^{a, b}$ Means with different superscripts in the same column are significantly $\operatorname{different}(\mathrm{P}<0.05)$.

초종별 $\mathrm{TMFF}$ 의 착유우에 대한 급여시험을 통한 기호성조사 결과는 표 5에서 보는 바와 같다. TMFF에 대한 젖소의 평균 일일 원물섭 취량은 알팔파-, 혼합목초-, 유채-, 옥수수-, 연맥-, 호맥-TMFF구에서 $62.85,60.48,58.04$, $57.11,54.61,45.74 \mathrm{~kg}$ 의 순서로 각각 높게 나 타내어 전체적으로 기호성이 우수한 것으로 나
타났으며, 호맥-TMFF구의 기호성이 가장 낮게 나타났다 $(\mathrm{P}<0.05)$. 이는 암모니아태질소와 부틸 산함량 등의 분석결과에서 나타난 것과 일치한 것이었다. 또한, TMFF 종류별 체중에 대한 건 물섭취율을 보면, 알팔파-, 옥수수-, 혼합목초-, 연맥-, 유채-, 호맥-TMFF구의 순서로 나타내 었으며, 호맥-TMFF구가 가장 낮은 $1.95 \%$ 였지 
만 이 수준은 단일 사료로서는 매우 높은 기호 성이라고 사료된다.

$\mathrm{TMFF}$ 의 급여시험기간 중의 체중변화와 체 충실지수(BCS)에 있어서 시험기간 60 일 동안 모든 공시축에서 체중증가가 있었으며, 기간의 평균 두당 일당증체량은 알팔파-, 혼합목초-, 옥수수-, 연맥-, 호맥-TMFF구의 순서로 326.7, $311.7,310.0,297.4,195.0,140.0 \mathrm{~g}$ 으로 각각 나 타내어 기호성이 좋았던 알팔파-TMFF구에서 역시 가장 높은 증체를 보였으며, 기호성이 가 장 낮았던 호맥-TMFF구에서 가장 낮은 증체 를 나타내었다 $(\mathrm{P}<0.05)$.

그리고 체충실지수에 있어서도 대부분의 시 험구에서 증가가 있었는데, 혼합목초-, 옥수수-, 유채-, 알팔파-, 연맥-, 호맥-TMFF구의 순으 로 증가치가 높게 나타내어 혼합목초-TMFF구
가 개시시의 3.07 에서 3.34 로 가장 크게 증가하 였고 호맥-TMFF구에서 3.34에서 3.30으로 약 간 감소하여 증체량과 체충실지수와는 비슷한 경향을 보였으나 일치하지는 않은 것으로 나타 내었다 $(\mathrm{P}<0.05)$.

이러한 결과는 $\mathrm{TMFF}$ 만 자유채식시켰음에도 착유우의 체중과 체충실지수가 증가하거나 유 지함을 보여주는 것으로써 $\mathrm{TMFF}$ 가 착유우의 체중유지를 위한 단일사료로서 충분한 가치가 있음을 나타내는 것으로 사료된다.

\section{TMFF 종류별 착유우의 우유생산성}

60 일간의 $\mathrm{TMFF}$ 급여기간 중 젖소의 평균 두당 우유생산성은 표 6 과 그림 1 에서 보는 바 와 같이 알팔파-, 연맥-, 혼합목초-, 옥수수-,

Table 6. Milk yield during the experimental periods

\begin{tabular}{ccccccccc}
\hline \multirow{2}{*}{ Items } & \multicolumn{9}{c}{ TMFFs } & \multirow{2}{*}{ Mean } & SEM \\
\cline { 2 - 6 } & Corn & Grass & Rye & Rape & Alfalfa & Oat & & \\
\hline \hline $\begin{array}{c}\text { Daily milk } \\
\text { yield(kg/hd) }\end{array}$ & $16.90^{\mathrm{bc}}$ & $17.20^{\mathrm{b}}$ & $16.16^{\mathrm{c}}$ & $16.16^{\mathrm{c}}$ & $18.95^{\mathrm{a}}$ & $18.12^{\mathrm{a}}$ & 17.25 & 1.11 \\
$\begin{array}{c}\text { Total milk } \\
\text { yield(Kg/hd) }\end{array}$ & $1,014^{\mathrm{bc}}$ & $1,032^{\mathrm{b}}$ & $969^{\mathrm{c}}$ & $970^{\mathrm{c}}$ & $1,137^{\mathrm{a}}$ & $1,087^{\mathrm{a}}$ & $1,034.8$ & 66.54 \\
\hline
\end{tabular}

${ }_{\mathrm{a}, \mathrm{b}}$ Means with different superscripts in the same column are significantly $\operatorname{different}(\mathrm{P}<0.05)$.

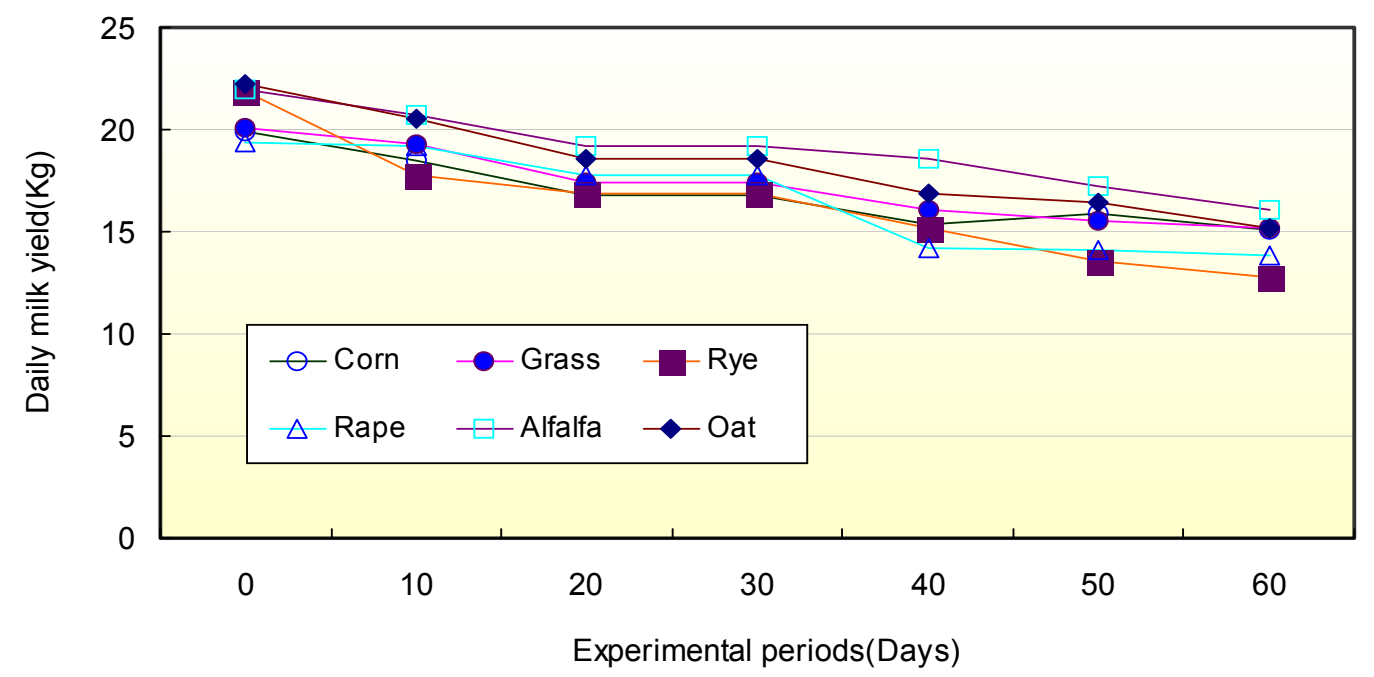

Fig. 1. Changes of mean daily milk yield during the experimental periods. 
Table 7. Effects of various TMFFs on milk compositions during the experimental periods in lactating cows

\begin{tabular}{cccccc}
\hline \multirow{2}{*}{ TMFFs } & \multicolumn{5}{c}{ Milk compositions(\%) } \\
\cline { 2 - 5 } & Fat & Protein & Lactose & SNF & TS \\
\hline \hline Corn & 4.40 & 3.45 & 4.67 & 8.81 & 12.74 \\
Grass & 4.67 & 3.54 & 4.65 & 8.80 & 13.00 \\
Rye & 4.11 & 3.23 & 4.45 & 8.86 & 12.97 \\
Rape & 4.79 & 3.45 & 4.59 & 8.71 & 12.57 \\
Alfalfa & 4.14 & 3.15 & 4.36 & 8.58 & 12.72 \\
Oat & 4.06 & 3.16 & 4.71 & 8.72 & 12.78 \\
Mean & 4.36 & 3.33 & 4.57 & 8.75 & 12.80 \\
SEM & 0.31 & 0.17 & 0.14 & 0.10 & 0.16 \\
\hline
\end{tabular}

SNF : Solid non fat ; TS : Total solids.

유채-, 호맥-TMFF구의 순서로 일일평균 18.95 , $18.12,17.2,16.9,16.16,16.16 \mathrm{~kg}$ 으로 시험구간 에 유의한 차이를 나타내었으며 $(\mathrm{P}<0.05)$, 일일 산유량의 변화에 있어서는 시험개시시의 평균 $21.2 \mathrm{~kg}$ 에서 60 일 후 시험 종료시에 모든 시험 구에서 $5 \mathrm{~kg}$ 정도 감소하였는데, 이는 $23 \%$ 수 준의 감소율로서 대부분의 시험축의 착유일수 가 300 일 이상의 비유말기에 이르렀기 때문으 로 사료된다. 이러한 결과로서 후기착유기에 있 는 착유우에게 $\mathrm{TMFF}$ 의 단일사료로 자유채식시 켰을 때, 다소 유량 감소가 나타나므로 산유량 의 지속성을 위해서는 농후사료 보충이 필요할 것으로 사료되며, 이를 구명하기 위한 농후사료 보충급여시험이 필요할 것으로 사료된다.

또한, 생산된 우유의 성분함량 중 평균지방 함량은 전체적으로 $4.06 \sim 4.79 \%$ 범위에서 매우 높은 유지방 함량을 나타내어 시험구별로는 유 채-, 혼합목초-, 옥수수-, 알팔파-, 호맥-, 연 맥-TMFF구의 순서로 높았으며, 단백질 함량은 $3.15 \sim 3.54 \%$ 범위에서 혼합목초-, 옥수수-, 유 채-, 호맥-, 연맥-, 알팔파-TMFF구의 순서로 높게 나타내었다. 또한, 유당 함량에 있어서는 전체 평균이 $4.56 \%$ 내외로서 서로 비슷한 함량 을 나타내었으며, 무지고형분량과 총 고형분 함량도 전체 평균이 $8.75 \%$ 와 $12.8 \%$ 내외로 시 험구간에 차이가 없는 것으로 나타내었는데,
TMFF 급여에 의해 우유중 성분 함량에 있어 서 유의한 차이를 나타나지 않았다 (Table 7).

IV. 요 약

본 연구는 6종류의 완전배합발효사료(Total mixed fermentation feed; TMFF)의 착유우에 대 한 영양적 가치를 구명하고자 수행되었다. 옥 수수, 혼합목초, 호맥, 유채, 알팔파 및 연맥의 6종의 사료작물 청예가 수확되었고, 볏짚과 밀 기울이 배합되었으며, 옥수수와 콩알곡을 배합 하였다. 그리고 각각의 배합물들은 40 톤 규모 의 트렌치 사일로에 진압-저장하였으며, 성분 분석과 젖소 급여시험을 위해 최소 60 일 이상 경과 후에 개봉하였다.

TMFF의 평균 건물 함량은 $23.98 \sim 28.42 \%$ 범위였으며, 조단백질 함량은 $16.2 \sim 19.2 \%$ 이었 고, 가소화영양소총량(TDN)은 $58.3 \sim 65.1 \%$ 수 준이었다. $\mathrm{ADF}$ 함량은 $34.4 \sim 39.6 \%$ 범위에서, $\mathrm{NDF}$ 함량은 $46.9 \sim 49.9 \%$ 범위를 나타내어 상 대적사료가치(RFV)는 유채-, 알팔파-, 혼합목 초-, 연맥-, 옥수수-. 호맥-TMFF에서 각각 $138.6,133.9,116.5,111.8,111.4,108.1$ 으로 나 타나, 호맥-TMFF의 것이 유의하게 낮은 것으 로 나타내었다 $(\mathrm{P}<0.05)$. 건물손실율은 0.8 $1.9 \%$ 범위로서 모든 $\mathrm{TMFF}$ 에서 양호한 발효와 
보관상태를 나타내었으며, $\mathrm{pH}$ 는 전체적으로 $3.89 \sim 4.87$ 이었으며, 암모니아태질소 $\left(\mathrm{NH}_{3}-\mathrm{N}\right)$ 함 량은 $6.93 \sim 8.66 \mathrm{mg} / \mathrm{d} \ell$ 이었다. 그리고 $\mathrm{TMFF}$ 원물내의 휘발성지방산 함량 중 초산 함량은 $0.19 \sim 0.57 \%$ 낮은 함량을 나타내었고, 젖산 함 량은 $1.17 \sim 3.21 \%$ 으로 매우 높게 나타내었으 며, 부틸산 함량은 $0.03 \sim 0.32 \%$ 로서 매우 낮게 나타나 $\mathrm{TMFF}$ 의 품질이 양호한 것으로 나타내 었다.

그리고 발효가 완료된 $\mathrm{TMFF}$ 를 평균 착유일 수 240일, 2.4산차, 44.3개월령, 일일산유량 21.2 $\mathrm{kg}$, 체중 $574.6 \mathrm{~kg}$, 체충실지수(BCS) 3.2 인 42 두에 무제한으로 급여하여 총 60 일간의 섭취량 조사와 월별 체중 및 $\mathrm{BCS}$ 를 조사한 결과, 초 종별 $\mathrm{TMFF}$ 의 평균 일일 총 섭취량은 알팔파-, 혼합목초-, 유채-, 옥수수-, 연맥-, 호맥-TMFF 구에서 $62.85,60.48,58.04,57.11,54.61,45.74$ $\mathrm{kg}$ 의 순서로 각각 높게 나타내어 전체적으로 기호성이 우수한 것으로 나타내었으며, 호맥 -TMFF구의 기호성이 가장 낮게 나타내었다 $(\mathrm{P}<0.05)$. 이때 젖소의 체중에 대한 $\mathrm{TMFF}$ 의 건 물섭취율은 $1.95 \sim 2.90 \%$ 로서 모든 $\mathrm{TMFF}$ 의 기 호성이 매우 우수한 것을 알 수 있었다.

$\mathrm{TMFF}$ 의 급여시험기간 중의 체중변화와 체 충실지수(BCS)에 있어서 시험기간 60 일 동안 모든 공시축에서 체중증가가 있었으며, 기간의 평균 두당 일당증체량은 $140.0 \sim 326.7 \mathrm{~g}$ 으로서 기호성이 가장 좋았던 알팔파-TMFF구에서 역 시 가장 높은 증체를 보였으며, 기호성이 가장 낮았던 호맥-TMFF구에서 가장 낮은 증체를 나타내었다 $(\mathrm{P}<0.05)$. 신체충실지수의 변화에 있 어서는 혼합목초-TMFF구가 개시시의 3.07 에서 3.34 로 가장 크게 증가하였고, 호맥-TMFF구에 서 3.34에서 3.30 으로 약간 감소하여 나타냄으 로서 증체량과 신체충실지수와는 비슷한 경향 을 보였으나 일치하지는 않은 것으로 나타내었 다 $(\mathrm{P}<0.05)$.

그리고 평균 두당 우유생산성은 알팔파-, 연 맥-, 혼합목초-, 옥수수-, 유채-, 호맥-TMFF구 의 순서로 일일평균 $16.16 \sim 18.95 \mathrm{~kg}$ 범위에서 시험구간에 유의한 차이를 나타내었으며 $(\mathrm{P}<0.05)$, 일일 산유량의 변화에 있어서는 시험
개시시의 평균 $21.2 \mathrm{~kg}$ 에서 60 일 후 시험 종료 시에 모든 시험구에서 $5 \mathrm{~kg}$ 정도 감소하여 나타 내었는데, 이는 시험종료시는 대부분의 시험축 의 착유일수가 300 일 이상의 비유말기에 이르 렀기 때문으로 사료된다.

우유의 성분 함량에 있어서 시험기간 중 평 균지방 함량은 전체적으로 $4.06 \sim 4.79 \%$ 범위에 서 매우 높은 유지방 함량을 나타내어 유채-, 혼합목초-, 옥수수-, 알팔파-, 호맥-, 연맥$\mathrm{TMFF}$ 구의 순서로 높았으며, 단백질 함량은 $3.15 \sim 3.54 \%$ 범위에서 혼합목초-, 옥수수-, 유 채-, 호맥-, 연맥-, 알팔파-TMFF구의 순서로 높게 나타내었다. 또한, 유당 함량에 있어서는 전체 평균이 $4.56 \%$ 내외로서 서로 비슷한 함량 을 나타내었으며, 무지고형분량과 총 고형분 함량에 있어서도 전체 평균이 $8.75 \%$ 와 $12.8 \%$ 내외로 시험구간에 차이가 없는 것으로 나타내 었는데, TMFF 급여에 의해 우유중 성분 함량 에 있어서 어떠한 경향을 찾을 수 없었다.

\section{$\mathrm{V}$. 인 용 문 헌}

1. A.O.A.C. 1990. Official Method of Analysis. (15th ed.). Washington, D.C.

2. Chaney, A. L. and Marbach, E. P. 1962. Modified reagents for determination of urea and ammonia. Clinical Chemistry. 8:130.

3. Duncan, D. B. 1955. Multiple range and multiple F test. Biometric. 11:1.

4. Edmonson, A. J., Lean, I. J., Weaver, L. D., Farver, T. and Webster, G. 1989. A body condition scoring chart for Holstein dairy cows. J. Dairy Sci. 72:68.

5. Erwin, E. S., Maro, G. J. and Emery, E. M. 1961. Volatile fatty acid analysis of blood and rumen fluid by gas chromatography. J. Dairy Sci. 44:1768.

6. Holland, C., Kezar, W., Kautz, W. P., Lazowshi, E. J., Mahanna, W. C. and Reinhart, R. 1990. Pioneer forage manual : A nutritional Guide, Pioneer Hi-bred International, Inc. p. 1

7. McCullough, M. E. 1986. Feeding dairy cows. Wisconsin. Fort Atkinson. P. 10. 
8. SAS. 1995. SAS / STAT Software for PC. Release 6.11, SAS Institute, Cary, NC, USA.

9. 강태홍, 차영호, 장윤환. 1980. 볏짚 사일리지 제 조시험 I П. 한국축산학회지. 22(6):439.

10. 고영두, 송도준. 1977. 한우에 대한 전분박강 silage 급여시험. 한국축산학회지. 19(5):370.

11. 김준식, 이현준, 조윤연, 지설하, 하종규, 한인규. 1989. 암모니아 및 가성소다 처리 볏짚급여가 젖 소의 산유능력에 미치는 영향. 한국낙농학회지. 11(2):65.

12. 문양수, 하종규, 고종열, 한인규. 1990. 볏짚의 사 료가치 개선에 관한 연구 I . 한영사보. 14(3): 84.
13. 문태현. 1994. 볏짚의 화학적 처리가 볏짚의 표 면구조위 변화, 반추위 미생물 부착 및 소화특성 에 미치는 영향. 서울대학교 박사학위 논문.

14. 신형태, 박윤창. 1980. 화학적처리에 의한 볏짚의 사료가치 증진연구. 한국축산학회지. 22(1):51.

15. 이남형, 김춘수, 육종륭. 1977. 볏짚의 사료가치 증진에 관한 연구. 한국축산학회지. 19(5):363.

16. 하종규, 이성실, 문태현, 이기종, 송만강, 이상철. 1993. 화학적처리에 의한 볏짚의 사료가치 증진 에 관한 연구 I -IV. 한국영양사료학회지. 17(4): 224.

(접수일자 : 2002. 8. 16 / 채택일자 : 2002. 12. 17) 